\title{
Q.
QNEEN'S
UNIVERSITY
BELFAST
}

\section{Development of the Consumer Refrigerator Safety Questionnaire (CRSQ): A Measure of Consumer Perceptions and Practices}

Cairnduff, V., Dean, M., \& Koidis, A. (2016). Development of the Consumer Refrigerator Safety Questionnaire (CRSQ): A Measure of Consumer Perceptions and Practices. Journal of Food Protection, 79, $1468-1646$. https://doi.org/10.4315/0362-028X.JFP-15-462

Published in:

Journal of Food Protection

Document Version:

Peer reviewed version

Queen's University Belfast - Research Portal:

Link to publication record in Queen's University Belfast Research Portal

Publisher rights

Copyright 2016 Ingenta.

\section{General rights}

Copyright for the publications made accessible via the Queen's University Belfast Research Portal is retained by the author(s) and / or other copyright owners and it is a condition of accessing these publications that users recognise and abide by the legal requirements associated with these rights.

Take down policy

The Research Portal is Queen's institutional repository that provides access to Queen's research output. Every effort has been made to ensure that content in the Research Portal does not infringe any person's rights, or applicable UK laws. If you discover content in the Research Portal that you believe breaches copyright or violates any law, please contact openaccess@qub.ac.uk. 


\section{DEVELOPMENT OF THE CONSUMER REFRIGERATOR SAFETY QUESTIONNAIRE (CRSQ): A MEASURE OF CONSUMER PERCEPTIONS AND PRACTICES}

Victoria Cairnduff, Moira Dean, Anastasios Koidis

Queen's University Belfast, Institute for Global Food Security, Belfast, Northern Ireland, UK.

Keywords: consumer; refrigerator; food storage; safety; perception; behavior; tool; instrument; questionnaire; handling; home

\section{Corresponding author:}

Dr Anastasios (Tassos) Koidis

Institute for Global Food Security, Queen's University Belfast, 18-30 Malone Road, Belfast, BT9 5BN, Northern Ireland, UK, tel: +44 28 90975569, email: t.koidis@ qub.ac.uk 


\section{ABSTRACT}

Food preparation and storage behaviors in the home deviating from the 'best practice' food safety recommendations may result in foodborne illnesses. Currently, there are limited tools available to fully evaluate the consumer knowledge, perceptions and behavior in the area of refrigerator safety. The current study aimed to develop a valid and reliable tool in the form of a questionnaire (CRSQ) for assessing systematically all these aspects. Items relating to refrigerator safety knowledge $(n=17)$, perceptions $(n=46)$, reported behavior $(n=30)$ were developed and pilot tested by an expert reference group and various consumer groups to assess face and content validity $(n=20)$, item difficulty and item consistency $(n=55)$ and construct validity $(n=23)$. The findings showed that the CRSQ has acceptable face and content validity with acceptable levels of item difficulty. Item consistency was observed for 12 out of 15 refrigerator safety knowledge. Further, all five of the subscales of consumer perceptions of refrigerator safety practices relating to risk of developing foodborne disease showed acceptable internal consistency (Cronbach's $\alpha$ value $\geq 0.8$ ). Construct validity of the CRSQ was shown to be very good $(\mathrm{p}=0.022)$. The CRSQ exhibited acceptable test-retest reliability at 14 days with majority of knowledge items (93.3\%) and reported behavior items (96.4\%) having correlation coefficients of greater than 0.70. Overall, the CRSQ was deemed valid and reliable in assessing refrigerator safety knowledge and behavior and therefore has the potential for future use in identifying groups of individuals at increased risk of deviating from recommended refrigerator safety practices as well as the assessment of refrigerator safety knowledge, behavior for use before and after an intervention. 
Approximately one million people suffer from a foodborne illness each year in the UK alone at an estimated cost of $£ 1.5$ bn (13). More modest numbers $(4,500)$ are officially recorded for Ireland (Health Protection Surveillance Centre for the Republic of Ireland and the Public Health Agency for Northern Ireland), although the unreported cases are considerably higher. Epidemiological data from Europe suggests that a substantial proportion of foodborne disease can be attributed to food preparation/storage behaviors that deviate from the 'best practice' food safety recommendations and between $50-87 \%$ of cases of food borne illness including Listeriosis may occur as result of a food prepared at home (33). A recent trend towards increasing incidence of Listeriosis in older adults (>60 years) has been observed internationally with lack of adherence to 'use by' dates on refrigerated foods and incorrect storage of refrigerated foods effectively being suggested as factors related to an increased risk of developing food poisoning (12). It has been previously suggested that consumers are unaware of the role that proper food safety practices in domestic food preparation plays in the prevention of food borne illness (15) with the majority believing that the responsibility lies with food manufacturers and restaurants (44). The findings of a study of 1020 households on the island of Ireland showed that over a third (38.9\%) of consumers perceived that $\leq 20 \%$ of cases of food borne illness occurred as a result of a food prepared at home (15). Shaw (36) stated that food safety experts in the UK have perceived an overall decrease in consumer knowledge in the area of food safety and hygiene in recent years. This decrease is thought to be associated with changes in the way practices were passed on and accepted by previous generations (36). Public food safety knowledge plays an important role in the development of risk assessment $(36,26)$. Consumer knowledge occurs as a result of both access to sources of information and motivation and effort on the part of the consumer to access the information (27). Knowledge has been shown to play a role in the formation of perceptions and beliefs and therefore, has an impact on current food safety practices and willingness to change 
current practices to bring them in line with 'best practice' guidelines (27). Associations between the socio-demographic characteristics of the individual (including age, gender, level of education, living environment, social class and participation in home economics training), risk awareness, food safety knowledge and behavior have also been observed $(9,33,36,42)$. Differences between reported and observed food safety behaviors have been observed (10, 18). In 2007, in response to increase in number of cases of listeriosis in adults aged over 60 years, the Food Standards Agency (FSA) ran a campaign to raise awareness of the need for correct handling of refrigerated food and 'use by' dates to prevent growth of listeria in refrigerated food. Following on from this, in 2009, the FSA in the UK published a report (14) which identified older adults (aged >60 years) as an 'at risk' group for the development of foodborne illness due to development of serious health problems and changes in their personal circumstances which may lead to food safety becoming less of a priority. The report also highlighted older adults as a key group to target with regards to food safety interventions/campaigns and in particular those in area of refrigerator temperature, storage of refrigerated food and access to refrigerator thermometers as older adults may be more likely to deviate from the current 'best practice guidelines' in these areas (14).

In parallel, in the way risk is communicated has changed: food safety awareness campaigns are now launched by relevant independent agencies worldwide (for example, in Ireland with safefood) with aim to influence existing practices (e.g. food handling), behaviors and, to a certain extent, increase consumer knowledge. The penetration of these campaigns however, is not easily measurable. In addition, modern domestic refrigerator include incremental technological advances in refrigerator design (door alarm, built-in thermometers, isolated bottom shelf) that promise to help consumers store food more efficiently. In this new environment, modern, robust and reliable tools are needed to assess consumer knowledge, perceptions and behavior relating to refrigerator safety to inform educational campaigns, to 
show the effect of their campaigns and to perhaps supplement to an extend the monitoring of the foodborne diseases.

Several previously validated tools have investigated aspects of consumer refrigerator safety knowledge, behavior and perceptions $(44,29,25,2,6,41,19,34,2,11)$. One study carried out developed a tool to assess the attitudes, practices and knowledge of college students in relation to food safety which incorporated aspects of refrigerator safety including refrigerator temperature, storing leftovers and 'use by dates' (40). A further study (1) developed a tool to assess observed refrigerator practices including the refrigerator contents (for example leftovers) and actual refrigerator temperature for older adults in receipt of a Meals on Wheels service in US. However the tool developed did not assess participant's knowledge and perceptions of refrigerator safety. Others (23) developed a web-based survey tool to investigate consumer refrigerator practices at home and incorporated questions on refrigerator thermometer ownership, reported refrigerator temperature and refrigerator cleanliness. However there are no validated tools currently available that have particularly focused on Consumer knowledge, behavior and perceptions of refrigerator safety, refrigerated foods, high risk, ready-to-eat foods, 'use by' dates and storage instructions etc., i.e. items that are crucial in building a modern food storage / food handling consumer profile. Therefore, the aim of the current study was to develop a valid and reliable tool for assessing current consumer knowledge, perceptions and behavior in the critical area of refrigerator safety, which will be fit for purpose, coherently validated, and easy to access electronically.

\section{METHODOLOGY}

The development of the Consumer Refrigerator Safety Questionnaire (CRSQ) was carried out in five main steps: 
Step 1: Review of literature and development of questionnaire items. A review of the literature and current 'best practice' guidelines in the area of refrigerator safety was carried out. The electronic databases PubMed and Google Scholar were searched using combinations of search terms in the following categories: Consumer ('consumer' and 'domestic'), Refrigerator ('refrigerator, 'refrigeration/methods', 'refrigeration/standards', 'food Handling/methods' and 'food handling/standards'), Food Safety ('food safety' and 'foodborne illness') and Knowledge/Behavior/Perceptions ('knowledge', 'behaviour', 'practices', 'attitudes' 'perceptions', ‘risk factors', 'guideline adherence'). The inclusion criteria were studies published in English between 1990 and 2013.. A review of current 'best practice' guidelines (2013) of the Food Safety agencies in UK and Island of Ireland (Safefood and Food Standards Agency) was also conducted.

Seven key areas were identified: refrigerator temperature control, placement of foods in the refrigerator, 'Use by' dates on high risk refrigerated foods, storage of food after opening, storage of leftovers, defrosting, refrigerator cleanliness. Due to a lack of specific refrigerator safety questionnaires assessing consumer knowledge, perceptions and behavior, a review of food safety knowledge questionnaires and study that applied the health belief model to area of refrigerator safety $(7,16,35)$ was carried out to generate an item pool. The final questionnaire consisted of 110 items within five sections: food responsibility, refrigerator safety knowledge, self-reported refrigerator behaviors, observed refrigerator behaviors (interviewer led refrigerator inspection), and perceptions of developing food poisoning from a food prepared at home (based on health belief model subscales perceived susceptibility, perceived severity, perceived barriers, perceived benefits and self-efficacy). Note that 'food responsibility' section was included to assess the extent to which the participant is responsible for shopping for food, preparing/ cooking food and stocking within their household. Each participant in the study was required to be responsible for at least half of 
food handling (i.e. shopping and stocking refrigerator) and preparation within their household.

Step 2: Assessment of face and content validity. Face validity is the extent to which the questionnaire items 'appear' to measure what they have been designed to measure where content validity refers to whether the items adequately cover all important aspects of the area to be investigated (22). Professionals who have experience of working with the population to be targeted or participants from the target population are good at assessing the face validity of a tool $(37,39)$. Content validity refers to whether the questionnaire items adequately cover all important aspects of the area to be investigated (22)- Here, face validity and content validity of the consumer refrigerator safety questionnaire (CRSQ) was assessed in an expert reference group of 10 individuals working the area of food safety. Face validity of the CRSQ was also assessed in a population reference group consisting of 10 consumers $(n=5$ aged 18-50 years and $n=5$ aged $51+$ years) who were responsible for at least half of food preparation and storage within their household but who are not specifically trained in the area of refrigerator safety.

\section{Step 3. Final Consumer Food Safety Questionnaire}

The final CRSQ had four main sections (see Supplementary Material for the full description of the items): Section A (Food Responsibility) included 3 questions to assess the extent to which the participant is responsible for food shopping, cooking/preparing food and stocking the refrigerator in their household with five response options based on likert scale (1=all or most; $2=$ more than half, $3=$ about half, $4=$ less than half; $5=$ not responsible for any). All study participants were required to be responsible for at least half food shopping, preparation of food and stocking of the refrigerator to be eligible for the study. Section B (Reported Refrigerator Behaviour) consisted of 15 questions in the areas of temperature control $(n=10)$, refrigerator cleanliness $(n=1), 1$ placement of foods $(n=1)$, 'use by' dates $(n=1)$ and storage 
instructions $(n=1)$. Section C (Refrigerator Safety Knowledge) consisted of 16 questions in the key areas of temperature control $(n=4)$, placement of foods in the refrigerator $(n=2)$, cooling and storing refrigerated leftovers $(n=2)$, refrigerator cleanliness $(n=1)$, defrosting foods $(n=3)$, use by dates/best before dates $(n=2)$, refrigerated foods $(n=1)$. The response choice format for all knowledge questions included five or six options for response including a 'don’t know' option. Section D (Food Poisoning Perceptions) included 40 items to assess consumer perceptions of susceptibility $(n=5)$ and severity $(n=6)$ of developing food poisoning, benefits of carrying out 'best practice' recommendations $(n=8)$ for preventing food poisoning, barriers to achieving 'best practice' refrigerator safety guidelines $(n=12)$ and selfefficacy for carrying out 'best practice' refrigerator safety recommendations $(n=9)$ (see Supplementary Material).

Step 4: Pilot study in target group for further development of the questionnaire. Study participants: The study received approval from the Research Ethics Committee within the School of Biological Sciences, Queens University Belfast. Overall, 55 participants $\geq 18$ years responsible for at least half of the food shopping, food preparation and stocking of refrigerator in their household completed the questionnaire. This group consisted of undergraduate 'Food and Nutrition' students/ final year students ( $\mathrm{n}=23)$ and consumers $(n=32)$ responsible for a least half of food preparation and food storage in their household but specifically trained in food safety.

Item difficulty and internal consistency: The level of item difficulty and discrimination associated with knowledge questions within a questionnaire impact on the reliability of the questionnaire (4). It has been suggested that knowledge items should be at a difficulty level that allows more than $20 \%$ but no greater than $80 \%$ of participants to identify the correct answer (31). Internal consistency is a measure of the correlations between different items within the same scale or subscale and Cronbach's $\alpha$ is the statistical test that is widely used to 
assess pairwise correlations between questionnaire items (8). Scales with Cronbach's $\alpha \geq 0.8$ have acceptable internal consistency and therefore this was used as the target figure for scales to be included.

Step 5: Test and retest reliability. In order to measure the reliability of the CRSQ for the assessment of consumer knowledge, perceptions and behavior relating to refrigerator safety it is essential that the results obtained are reproducible and stable in the different conditions in which the tool is designed to be used (5). Test-retest reliability was assessed in a group of 20 individuals who completed the questionnaire on two separate occasions 14 days apart. This group consisted of 10 postdoctoral researchers and $\mathrm{PhD}$ students of the Institute for Global Food Security (QUB) working in the agri-food area and their family members $(n=10$, not trained in food safety aspects. A time interval of 14 days is frequently used within test-retest reliability studies, as it is suggested to be long enough to allow enough time for original answers to be forgotten but short enough to limit changes in knowledge and perceptions (38). Pearson correlation analysis was used to assess intra-individual correlations for scores in each item of refrigerator safety knowledge and behavior items. A cut-off $>0.7$ was used to assess acceptable reliability of the CRSQ for assessing consumer refrigerator safety knowledge and perceptions over time.

\section{RESULTS AND DISCUSSION}

Face and content validity (Initial test phase, $n=20$ ). The first stage was to conduct face validity of the CRSQ to evaluate its effectiveness. Without initially establishing face validity, it is uncertain whether the final tool has content validity $(22,31)$.

Face validity and content validity were assessed in an expert a population reference group $(\mathrm{n}=10)$ and population reference. Following this initial test phase of the CRSQ, minor 
changes were made before the pilot study was carried out. These changes included: (1) The addition of a 'don't know' response option of knowledge questions, (2) the rewording of the questions assessing the presence of a refrigerator thermometer and thermostat knowledge to improve clarity, (3) the addition of a question assessing the presence of a LCD temperature display within the reported behavior section and (4) the addition of further options for response that deviate from the current 'best practice' guidelines but may reflect consumer refrigerator safety knowledge and behavior, for example 'where there is space' was added as a response option for the question 'Where is the safest place to store raw meat in your refrigerator?' and 'If food feels warmer', 'If food feels colder' and 'never check refrigerator temperature' response options were added to 'How often is the temperature in your refrigerator checked?'.

The demographic information for the final version of CRSQ is presented in Table 1. A pilot study of the final CRSQ was carried out to assess 'item difficulty' for the knowledge questions $(\mathrm{n}=15)$ and 'internal consistency' for refrigerator safety knowledge, reported behavior and perceptions. In terms of 'Item Difficulty', overall, 12 out of 15 knowledge questions had an acceptable level of item difficulty with one item assessing consumer knowledge of recommended place for a refrigerator thermometer having higher level of item difficulty with only $12.7 \%$ participants identifying the correct answer. Also two items assessing consumer knowledge of the safest place to store raw meat and the correct definition of a 'best before' date showed lower levels of item difficulty with $7.2 \%$ and $10.8 \%$ participants selecting the incorrect answer respectively. However as the three items that demonstrated higher/lower item difficulty covered three of key areas of refrigerator safety that were not covered in other items within the questionnaire, they were retained in order to maintain content validity. Internal Consistency: Overall the findings of the Cronbach's $\alpha$ analysis demonstrated acceptable internal consistency was observed for all five subscales 
within the health belief model (susceptibility, severity, benefits, barriers, self-efficacy) having a Cronbach's $\alpha \geq 0.8$ (Table 2).

Test-retest reliability. In terms of the test-retest reliability for the refrigerator safety knowledge questions, 14 of 15 items had a correlation coefficient $\geq 0.70$ with the item relating to 'use by' definition of having correlation coefficient of 0.66 (Table 3). Six refrigerator safety knowledge items (leftover knowledge, refrigerator cleanliness, length of time that is safe to eat a cooked food after defrosting, safest place to store red meat, 'best before' definition and length of time perishable food can be stored at room temperature before becomes unsafe to consume) had a correlation coefficient of 1.00 ( $p<0.001)$. Three refrigerator safety knowledge items (recommended operating temperature for refrigerator, recommended place for refrigerator thermometer, length of time to cook raw meat after defrosted) had correlation coefficients between 0.80 and 0.89 ( $\mathrm{p}<0.001)$. Five items (most important information to be considered to determine if food is safe to eat, safest method for checking refrigerator temperature, length of time to eat refrigerated food, coldest part of the refrigerator, safest methods for defrosting raw meat) have slighted lower correlation factors (0.70-0.80) (Table 3).

For the test-retest reliability on reported refrigerator safety behavior, 27 out of 28 behavior items had a correlation coefficient $\geq 0.70$ (Table 4). For nine of the reported refrigerator safety behavior items (frequency with which refrigerator temperature is checked, usual method for checking if refrigerator is operating within the recommended range, way to turn thermostat to lower refrigerator temperature, placement of raw meat and poultry, frequency 'use by' date is checked before freezing and consuming food, how often fresh meat, fruit and vegetables, ready meals and yogurt are consumed after 'use by' date and how often fresh meat, cooked meat, convenience foods e.g. pasta sauce, yogurt and ready meals are consumed past the 
storage instructions on food label), the correlation coefficient was 1.00 ( $\mathrm{p}<0.001)$. In total, seven of the reported refrigerator safety behavior items (having an appropriate thermometer present in refrigerator, how often milk, cooked meats, convenience foods e.g. pasta sauce and prepared salads, e.g. coleslaw are consumed past 'use by' date on label, the way that the refrigerator thermostat dial is turned to make refrigerator colder and last refrigerator temperature reading in $\left.{ }^{0} \mathrm{C}\right)$ had a correlation coefficient $0.80-0.89(\mathrm{p}<0.001)$. Two of reported refrigerator behavior items (frequency with which the 'use by' date on a food label is checked before buying food and how often cheese is eaten past use by date) had correlation coefficient of $0.70-0.79(\mathrm{p}<0.05)$ (Table 4). All five subscales assessing consumer perceptions of refrigerator safety for reducing the risk of developing food poisoning have demonstrated acceptable test-retest reliability with correlation co-efficients $>0.70$ (Table 5).

The purpose of this study was to develop a valid and reliable questionnaire (CRSQ) to assess consumer refrigerator safety knowledge, perceptions and behavior for use in research studies aimed at assessing changes in consumer knowledge, perceptions and practices over time and following refrigerator safety awareness campaigns and updated 'best practice' guidelines by food safety agencies. Another potential use of the CRSQ would be to assess refrigerator safety knowledge, perceptions and behavior before and after a refrigerator safety intervention. Although some validated tools for assessing food safety knowledge and behavior in different populations are currently available within the literature $(20,28,30)$, the CRSQ refrigerator safety questionnaire is unique in the way it assesses consumer knowledge (17 items), perceptions (46 items) and behavior (30 items) that specifically relate to the seven key areas of refrigerator safety that have been identified within the literature and in the recommendations food safety agencies in both the Republic of Ireland and the UK. Overall, the CRSQ takes approximately 35-40 min to complete and can take the form of either an interview led or self-completion questionnaire which makes it practical for use within 
research studies of different designs. The validity of the CRSQ has been assessed using a variety of techniques (face and content validity).

The CRSQ has also exhibited acceptable levels of construct validity with students from biological science background (high level of food safety knowledge) achieving higher scores within the refrigerator safety and perceived severity subscales when compared with those studying other subjects. These findings suggest that higher levels of refrigerator safety knowledge and perceived severity of and are comparable to those findings observed by similar studies within the literature investigating consumer food safety knowledge, attitudes and behaviors which have shown that higher food safety knowledge is not always translated into practice $(32,42,43)$. Following review of the CRSQ items that did not meet the criteria in terms of item difficulty $(n=3)$, and test-retest reliability $(n=2)$ it was decided that the questionnaire items should remain to maintain content validity of the questionnaire (21) and to ensure each of seven key areas of refrigerator safety was covered within knowledge, perceptions and behavior subscales.

The findings of the CRSQ test-retest reliability study showed that 14 of 15 food safety knowledge items and 27 of 28 reported behavior items had intra-individual correlation coefficients of $>0.70$ and have, therefore, indicated that the questionnaire is acceptable for assessing refrigerator safety knowledge and reported refrigerator safety behavior over time. These findings suggest that the tool is valid for use in further studies to evaluate consumer knowledge, perceptions and behavior relating to the current 'best practice' recommendations for refrigerator safety. The results, amongst others, can be used in aiding the development of future evidence-based awareness campaigns and refrigerator safety interventions $(17,46)$.

Although the validity of the CRSQ has not yet been assessed on an international level, the questionnaire items were developed to reflect the key areas of refrigerator safety identified 
within the international peer reviewed literature. A further limitation of the CRSQ due to the changing nature of refrigerator design and therefore refrigerator safety recommendations, the CRSQ will need to be reviewed on a regular basis to ensure content validity.

In conclusion, the findings showed that the survey tool developed in this study (CRSQ) has acceptable face and content validity with acceptable levels of item difficulty. Construct validity, internal consistency within different subscales of consumer perceptions and testretest reliability of the CRSQ was shown to be very good. Overall, the CRSQ was presumed reliable in assessing refrigerator safety knowledge and behavior and therefore has the potential for future use in identifying groups of individuals at increased risk of deviating from recommended refrigerator safety practices (elderly, young adults and others) and of risk of developing foodborne disease as well as the assessment of refrigerator safety knowledge, behavior for use before and after an intervention.

\section{ACKNOWLEDGEMENTS}

This study was carried out with financial support safefood, the agency that promotes awareness and knowledge of food safety and nutrition issues on the island of Ireland, project 03-2013, titled 'A study of domestic refrigerators on the island of Ireland- temperature control, design and consumer practices'. It does not necessarily reflect its views and in no way anticipates the agency's future policy in this area.

\section{SUPPLEMENTARY MATERIAL}

Full items of Consumer Refrigerator Safety Questionnaire (CRSQ). Please go to:

http://go.qub.ac.uk/Scdbc 


\section{REFERENCES}

1. Albrecht, J. A. and C. Larvick. 2007. Refrigerator practices of participants in the Meals on Wheels program. Food Prot Trends. 27:672-677

2. Anderson, A., L.A. Verrill, and N.R. Sahyoun. 2011. Food Safety Perceptions and Practices of Older Adults. Public Health Rep. 126: 220-227

3. Anderson, J.B, T.A. Shuster, K.E. Hansen, A.S. Levy, and A.Volk 2004. A Camera's view of consumer Food Handling Behaviors. J Am Diet Assoc. 104:186-191

4. Brenner, M. H. 1964. Test difficulty, reliability and discrimination as functions of item difficulty order. J. Appl. Psych. 48:98-100.

5. Brown, W. J., S. G. Trost, A. Bauman, K. Mummery, and N. Owen. 2004. Test-retest reliability of four physical activity measures used in population surveys. J. Sci. Med. Sport 7:205-215.

6. Byrd-Bredbenner, C., J.Maurer, V. Wheatley, , E. Cottone, and M. Clancey, 2007. Food Safety Hazards Lurk in the kitchens of young Adults. J Food Prot.. 70:4:991996

7. Clayton, D. A., C. J. Griffith, P. Price, and A. C. Peters. 2002. Food handlers' beliefs and self-reported practices. Int. J. Environ. Heal. R. 12:25-39.

8. Cronbach, L. J. 1951. Coefficient alpha and the internal structure of tests. Psychometrika, 16(3), 297-334

9. De Boer, M., M. McCarthy, M. Brennan, A. L. Kelly, and C. Ritson. 2005. Public understanding of food risk issues and food risk messages on the Island of Ireland: The views of food safety experts. Rna 25:241-265

10. Dharod, J. M., R. S. Perez-Escamilla, S. Paciello, A. Bermudez-Millan, K. Venkitanarayanan, and G. Damio. 2007. Comparison between self-reported and observed food handling behaviors among Latinas. J. Food Prot. 70:1927-1932. 
11. Ergonul, B 2013. Consumer awareness and perception to food safety: A consumer analysis. Food Control. 32:461-471

12. Evans, E. W., and E. C. Redmond. 2015. Analysis of Older Adults' Domestic Kitchen Storage Practices in the United Kingdom: Identification of Risk Factors Associated with Listeriosis. J. Food Prot. 4:8:738-745.

13. Food Standards Agency - FSA. 2010. Foodborne Disease Strategy 2010-2015. http://www.food.gov.uk/sites/default/files/multimedia/pdfs/fds2015.pdf (Accessed $30 / 9 / 15)$.

14. Giles E.L. 2009. Older people and food: a synthesis of evidence. Social Science Research Unit. Food Standards Agency, p1-83.

15. Griffith, C., D. Worsfold, and R. Mitchell. 1998. Food preparation, risk communication and the consumer. Food Control 9:4:225-232.

16. Hanson, J. A., and J. A. Benedict. 2002. Use of the Health Belief Model to examine older adults' food-handling behaviors. J. Nutr. Educ. Behav. 34:S25-S30.

17. Hislop, N., and K. Shaw. 2009. Food safety knowledge retention study. J. Food Prot. $72: 431-435$.

18. Jay, L. S., D. Cormar, and L. D. Govenlock. 1999. A video study of Australian domestic food handling practices. J. Food Prot., 62, 1285-1296

19. Jevsnik, M., V. Hlebec, and P. Raspor, 2008. Consumers Awareness of Food Safety from shopping to eating. Food Control. 19:737-745.

20. Kendall, P. A., A. Elsbernd, K. Sinclair, M. Schroeder, G. Chen, V. Bergmann, V. N. Hillers, and L. C. Medeiros. 2004. Observation versus self-report: validation of a consumer Food Behaviour Questionnaire. J. Food Prot. 11:2368-2626. 
21. Kennedy, J., V. Jackson, I. S. Blair, D. A. McDowell, C. Cowan, D. J. and Bolton. 2005. Food Safety Knowledge of Consumers and the Microbiological and Temperature status of their refrigerators. J. Food Prot. 68:7:1421-1430.

22. Kline (2000). The Handbook for psychometric testing ( $2^{\text {nd }}$ Edition). London, UK: Routledge.

23. Kosa, K.M., S.C. Cates, S. Karns, S.L. Godwin,., and D Chambers 2007. Consumer Home Refrigeration Practices: Results of a Web-Based Survey. J. Food Prot.. 70:7:1640-1649.

24. Lavrakas, P. J. 2008. Construct Validity. Encyclopaedia of Survey Research Methods. Accessed $30^{\text {th }}$ June 2015 at http://srmo.sagepub.com/view/encyclopedia-of-surveyresearch-methods/n92.xml.

25. Li-Cohen, A.E. and C.M. Bruhn2002. Safety of Consumer Handling of Fresh Produce from the Time of Purchase to the plate: A comprehensive Consumer Survey. J. Food Prot.. 65:8:1287-1296.

26. McCarthy, M., M. Brennan, A. L. Kelly, C. Ritson, M. De Boer, and N. Thompson. 2007. Who is at risk and what do they know? Segmenting a population on their food safety knowledge. Food Qual Pref., 18:2:205-217.

27. McIntosh, W. A., L. B. Christensen, and G. R. Acuff. 1994. Perceptions of risks of eating undercooked meat and willingness to change cooking practices. Appetite 22:83-96.

28. Medeiros, L. C., V. N. Hillers, G. Chen, V. Bergmann, P. Kendall, M. Schroeder, 2004. Design and Development of food safety knowledge and attitude scales for food safety education. J Acad. Nutr. Diet. 104:1671-1677. 
29. Meer, R.R. and S.L. Misner 2000. Food Safety Knowledge and behaviour of Expanded Food and Nutrition Education Program Participants in Arizona. J. Food Prot.. 63: 12:1725-1731

30. Moghaddam, A. F., F. Khoshnevisan, D. Bondarianzadeh, M. Mohammadi, and H. Bakhshandeh. 2014. Development of a food safety attitude and practice questionnaire for Iranian consumers. Int. J. Consum. Stud. 38:367-373.

31. Parmenter, K. and J. Wardle. 2000. Evaluation and design of nutrition knowledge measures. J. Nutr. Educ., 32:269-277.

32. Patah, M. O. R. A, Z. M. Issa, and K. M. Nor. 2009. Food Safety Attitude of Culinary Arts students in public and private higher learning institutions. Int. Educ. Stud. 2:168178.

33. Redmond, E. C.and C. J. Griffith. 2003. Consumer Food handling in the home: a review of food safety studies. J. Food Prot. 66:130-161.

34. Sanlier, N. 2009. The knowledge and practice of food safety by young and adult consumers. Food Control. 20:538-542.

35. Schafer, R. B., E. Schafer, G. L. Bultena, and E. O. Hoiberg. 1993. Food safety: An application of the health belief model. J. Nutr. Edu., 25:17-24.

36. Shaw A. 2003. Public understanding of food risks: expert and lay views. Food Info Online, 2-3.

37. Steyn, N. P., D. Labadarios, J. H. Nel, and H.-L. Robertson. 2005. Development and validation of a questionnaire to test knowledge, practices of Dieticians using dietary supplements. Nutrition, 21:51-58.

38. Streiner D., and G. Norman. 1995. Health measurement scales: a practical guide to their development and use. $2^{\text {nd }}$ ed. Oxford, UK: Oxford University Press. 
39. Talmage, H, and S. Rasher. 1981. Validity and reliability issues in measurement instruments. J. Nutr. Educ., 13:83-85.

40. Unklesbay, N, J. Sneed, R. Toma.1998. College Student's Attitudes, Practices and Knowledge of Food Safety. J. Food Prot. 61:9:1175-1180

41. Unusan, N 2007. Consumer Food Safety knowledge and practices in the home in Turkey. Food Control. 18:45-51

42. Wilcock, A., M. Pun, J. Khanona, and M. Aung. 2004. Consumer attitudes, knowledge and behaviour: a review of food safety issues. Tr. Food Sci. Tech. 15:256266.

43. Woodburn, M. J., and A. C. Radb. 1997. Household food preparer's food safety knowledge and practices following widely publicised outbreaks of food borne illness. J. Food Prot. 60:1105-1109.

44. Worsfold, D. and C. Griffith.1997.Food safety behaviour in the home. Brit Food J. . 99:3 97:104

45. Worsfold, D., and C. J. Griffith. 1997. Assessment of the standard of consumer food safety behavior. J. Food Prot., 60:4:399-406.

46. Yarrow, L., V. M. Remig, and M. M. Higgins. 2009. Food safety educational intervention positively influences college students' food safety attitudes, beliefs, knowledge, and self-reported practices. J. Environ. Health, 71:30-35. 
Table 1. Demographic characteristics of participants in CRSQ Validation and test- retest reliability studies $(\mathrm{n}=98)$.

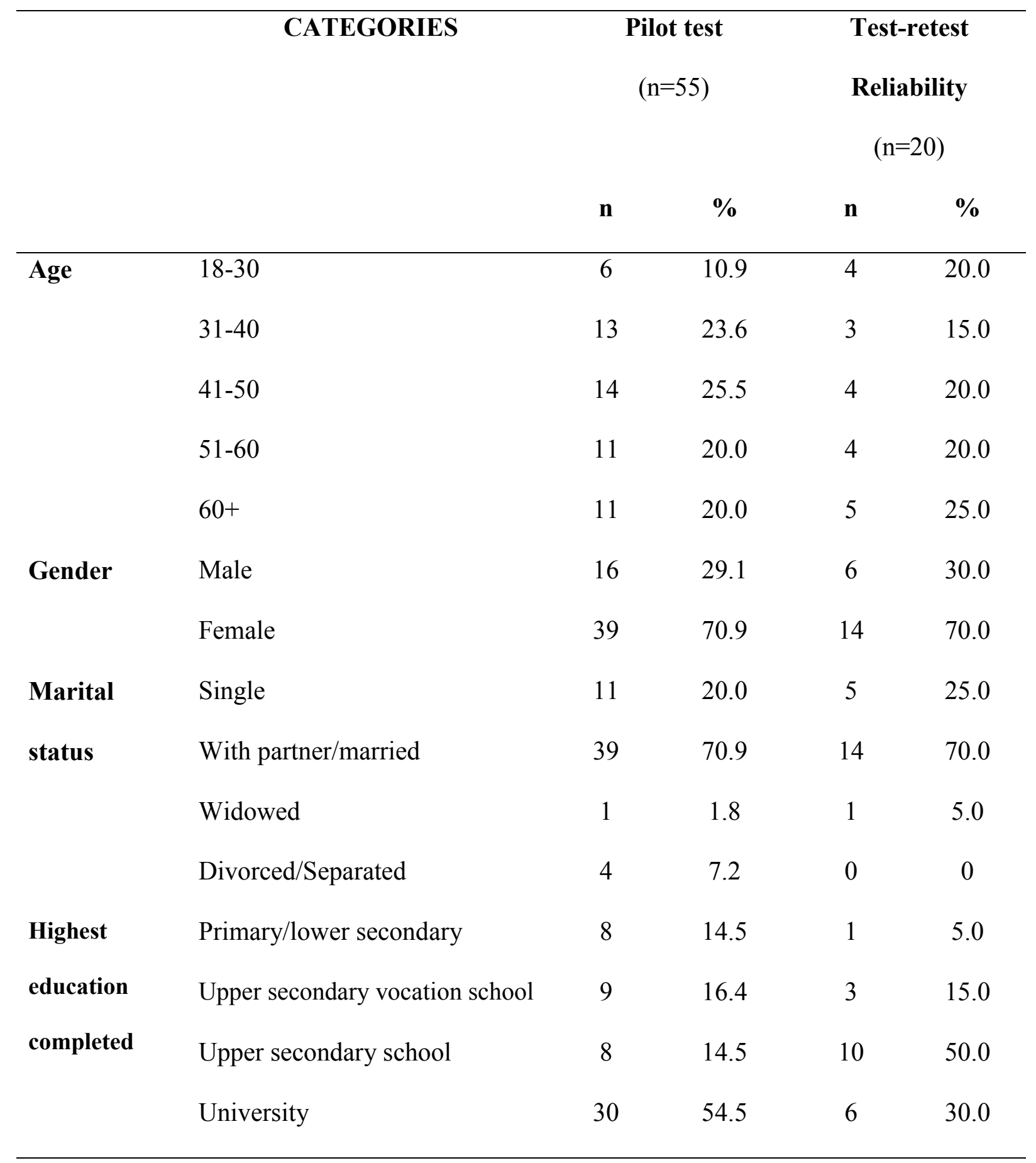


Table 2. Pilot study: Mean, standard deviation, range and Cronbach's $\alpha$ values for consumer perceptions and knowledge relating to refrigerator safety recommendations for prevention food poisoning $(\mathrm{n}=55)$.

\begin{tabular}{cccccc}
\hline & No.of items & Range & Mean & Std. Deviation & $\boldsymbol{\alpha}^{*}$ \\
\hline Perceived & 6 & $1.33-5.00$ & 3.82 & 0.80 & 0.84 \\
susceptibility $§$ & & & & & \\
Perceived severity $\|$ & 5 & $1.40-5.00$ & 3.85 & 0.83 & 0.85 \\
Perceived benefits \# & 8 & $1.00-5.00$ & 3.96 & 0.76 & 0.93 \\
Perceived barriers** & 12 & $1.00-5.00$ & 4.13 & 0.92 & 0.95 \\
Self-efficacy $\$ \S$ & 9 & $1.44-5.00$ & 3.98 & 0.73 & 0.92 \\
Refrigerator safety & 15 & $2.50-12.50$ & 7.68 & 1.85 & 0.80 \\
knowledge \# \# & & & & & \\
\hline
\end{tabular}

* crobachs alpha value

$\S$ Perceived susceptibility to developing food poisoning from food prepared at home, a summation of six likert-type items ( $1=$ strongly disagree to 5 strongly agree)

|| Perceived severity of development of food poisoning from a food prepared at home, a summation of five likert-type items ( $1=$ strongly disagree to 5 strongly agree)

\# Perceived benefits of carrying out 'best practice' refrigerator safety recommendations in prevention of food poisoning from a food prepared at home, a summation of eight likert-type items ( $1=$ strongly disagree to 5 strongly agree)

** Perceived barriers of carrying out 'best practice' refrigerator safety recommendations, a summation of twelve likert-type items ( $1=$ no problem to $5=$ a big problem)

$\S \S$ Self-efficacy self-confidence to get information on and follow the current recommendations for refrigerator safety, a summation of nine likert-type items ( $1=$ strongly disagree to 5 strongly agree)

\# \# Refrigerator safety knowledge a summation of 15 items based on correct or not correct $(1=$ correct and $0=$ not correct $)$. 
Table 3. Test-retest reliability study: Intra-individual correlation coefficients for refrigerator safety knowledge items $(n=20)$.

\begin{tabular}{|c|c|c|}
\hline \multirow[b]{2}{*}{ Knowledge } & \multicolumn{2}{|l|}{ Correlation } \\
\hline & Coefficient & $\mathbf{p}$ \\
\hline Recommended refrigerator operating temperature & 0.899 & $<0.001$ \\
\hline Coldest part of refrigerator & 0.729 & $<0.001$ \\
\hline Recommended place for refrigerator thermometer & 0.839 & $<0.001$ \\
\hline Safest method for checking refrigerator temperature & 0.789 & $<0.001$ \\
\hline Leftover knowledge & 1.000 & $<0.001$ \\
\hline Refrigerator cleanliness & 1.000 & $<0.001$ \\
\hline Safest ways to defrost raw meat & 0.713 & 0.001 \\
\hline Length of time to cook raw meat after defrosted & 0.839 & $<0.001$ \\
\hline Length of time to eat a cooked food after defrosted & 1.000 & $<0.001$ \\
\hline Safest place to store raw meat & 1.000 & $<0.001$ \\
\hline Length of time safe to eat refrigerated food & 0.760 & $<0.001$ \\
\hline 'Use by' date definition & 0.659 & 0.002 \\
\hline 'Best before' date definition & 1.000 & $<0.001$ \\
\hline $\begin{array}{l}\text { How long perishable food can be stored at room } \\
\text { temperature before becomes unsafe to eat }\end{array}$ & 1.000 & $<0.001$ \\
\hline $\begin{array}{l}\text { Most important information to consider when } \\
\text { determining if a food is safe to eat }\end{array}$ & 0.782 & $<0.001$ \\
\hline
\end{tabular}


Table 4. Test-retest reliability study: Intra-Individual correlation coefficients for reported refrigerator safety behavior items $(n=20)$.

\section{Reported behavior}

Correlation

coefficient

\begin{tabular}{|c|c|c|}
\hline Current refrigerator temperature & 0.874 & $<0.001$ \\
\hline Having refrigerator thermometer present & 0.899 & $<0.001$ \\
\hline Last temperature reading $\left({ }^{0} \mathrm{C}\right)$ & 0.797 & $<0.001$ \\
\hline Frequency with which refrigerator temperature checked & 1.000 & $<0.001$ \\
\hline Usual method for checking if refrigerator is operating within & 1.000 & $<0.001$ \\
\hline \multicolumn{3}{|l|}{ recom. range } \\
\hline Refrigerator thermostat knowledge & 0.889 & $<0.001$ \\
\hline Way turn thermostat to lower refrigerator temperature & 1.000 & $<0.001$ \\
\hline Frequency with which refrigerator is cleaned & 0.687 & 0.001 \\
\hline Placement of raw meat & 1.000 & $<0.001$ \\
\hline Placement of raw poultry & 1.000 & $<0.001$ \\
\hline Frequency checking 'use by' date before buying food & 0.792 & $<0.001$ \\
\hline Frequency checking 'use by' date before preparing food & 0.864 & $<0.001$ \\
\hline Frequency checking 'use by' date before freezing food & 1.000 & $<0.001$ \\
\hline Frequency checking 'use by' date before consuming food & 1.000 & $<0.001$ \\
\hline How often fresh meat is eaten past 'use by' date & 1.000 & $<0.001$ \\
\hline How often fruit, veg and salad is eaten past 'use by' date & 1.000 & $<0.001$ \\
\hline How often cooked meats are eaten past 'use by' date & 0.880 & $<0.001$ \\
\hline How often ready meals is eaten past 'use by' date & 1.000 & $<0.001$ \\
\hline How often convenience foods eaten past 'use by' date & 0.864 & $<0.001$ \\
\hline How often milk is consumed past 'use by' date & 0.896 & $<0.001$ \\
\hline
\end{tabular}


How often cheese is eaten past 'use by' date

How often yogurt is eaten past 'use by' date

How often prepared salads e.g. coleslaw are eaten past 'use

by' date

How often fresh meat is eaten past 'Storage instructions'

How often cooked meats are eaten past 'storage

instructions'

How often convenience foods are eaten past 'Storage

instructions'

How often yogurt is eaten past 'Storage instructions' 
Table 5. Test-retest reliability study: Intra-Individual correlation coefficients for Consumer Perceptions of Refrigerator safety to reduce risk of developing food poisoning $(n=40)$

\begin{tabular}{cccc}
\hline & $\begin{array}{c}\text { Number of } \\
\text { items }\end{array}$ & $\begin{array}{c}\text { Correlation } \\
\text { Coefficient }\end{array}$ & P \\
\hline Perceived Susceptibility & 6 & 0.960 & $<0.001$ \\
Perceived Severity & 6 & 0.847 & $<0.001$ \\
Perceived Benefits & 8 & 0.996 & $<0.001$ \\
Perceived Barriers & 10 & 0.976 & $<0.001$ \\
Perceived Self-Efficacy & 12 & 0.800 & $<0.001$ \\
\hline
\end{tabular}




\section{Development of the Consumer Refrigerator Safety Questionnaire (CRSQ): A Measure of Consumer Perceptions and Practices}

Victoria Cairnduff, Moira Dean, Anastasios Koidis

Queen's University Belfast, Institute for Global Food Security, Belfast, Northern Ireland, UK.

To be published in the Journal of Food Protection

\section{SUPPLEMENTARY INFORMATION}

Table S1. Full items of Consumer Refrigerator Safety Questionnaire (CRSQ).

SECTION A: FOOD RESPONSIBILITY

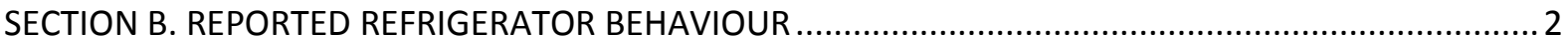

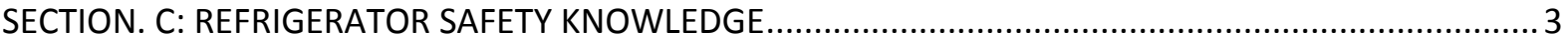

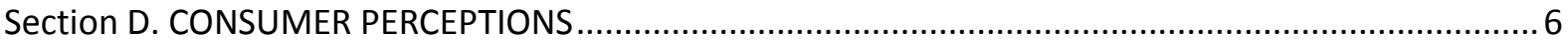

\section{SECTION A: FOOD RESPONSIBILITY}

\begin{tabular}{|l|l|}
\hline Question & Response options \\
\hline $\begin{array}{l}\text { Extent you are responsible for each of the following in your } \\
\text { household; Food shopping; Cooking and preparing food; Stocking } \\
\text { the refrigerator }\end{array}$ & $\begin{array}{l}\text { All or most } \\
\text { More than half } \\
\text { About half } \\
\text { Less than half }\end{array}$ \\
$\begin{array}{l}\text { How often is the main shopping normally carried out in your } \\
\text { household }\end{array}$ & $\begin{array}{l}\text { Every day; Twice a week; } \\
\text { Once a week; fortnight; } \\
\text { month }\end{array}$ \\
\hline $\begin{array}{l}\text { On which day is the main food shopping normally carried out in } \\
\text { your household? }\end{array}$ & $\begin{array}{l}\text { Monday; Tuesday; (rest of } \\
\text { the week days) }\end{array}$ \\
\hline
\end{tabular}




\begin{tabular}{|c|c|}
\hline $\begin{array}{l}\text { How often does you visit the shops (other than your main shop) to } \\
\text { pick small quantities of food (top up shopping)? }\end{array}$ & $\begin{array}{l}\text { Every day ; Every } 2-3 \text { days; } \\
\text { Every } 4-5 \text { days; Once a } \\
\text { week; fortnight; month; }>1 \text { a } \\
\text { month }\end{array}$ \\
\hline When did you do your last main food shop? & $\begin{array}{l}\text { Today; Yesterday; Two days } \\
\text { ago; 3-4 days ago; 5-6 days } \\
\text { ago; Other (specify) }\end{array}$ \\
\hline $\begin{array}{l}\text { main food shop, how long does it usually take between } \\
\text { completing the shop to unpacking your shopping? }\end{array}$ & $\begin{array}{l}\text { Up to } 1 / 2 \text { hour; } 1 / 2-1 \text { hour; } 1-2 \\
\text { hours; } 2-4 \text { hours; } 4 \text { hours+ }\end{array}$ \\
\hline \multicolumn{2}{|l|}{ SECTION B. REPORTED REFRIGERATOR BEHAVIOUR } \\
\hline $\begin{array}{l}\text { Temperature control Do you know what temperature your } \\
\text { refrigerator is currently set at? }\end{array}$ & $\begin{array}{l}\text { Yes; } \\
\text { No; } \\
\text { Don't know }\end{array}$ \\
\hline $\begin{array}{l}\text { Do you have an LCD temperature display on your refrigerator? If } \\
\text { yes what was the reading the last time was checked? }\end{array}$ & \multirow{2}{*}{$\begin{array}{l}\text { Yes; } \\
\text { No } \\
\text { Open response temperature } \\
{ }^{\circ} \mathrm{C}\end{array}$} \\
\hline $\begin{array}{l}\text { Do you have a refrigerator thermometer? } \\
\text { If yes what was the reading when checked? }\end{array}$ & \\
\hline How often is the temperature in your refrigerator checked? & $\begin{array}{l}\text { Once a day; Once a week; } \\
\text { Once a fortnight; Every } \\
\text { month; Every } 3,6 \text { months; If } \\
\text { food feels warmer; If food } \\
\text { feels colder; Other (please } \\
\text { specify); Never }\end{array}$ \\
\hline How do you normally check if your refrigerator is cold enough? & $\begin{array}{l}\text { Food feels cold / warm; Take } \\
\text { a thermometer reading; Use } \\
\text { manufacturers } \\
\text { recommendation for setting } \\
\text { the thermostat; LCD display; } \\
\text { Don't know }\end{array}$ \\
\hline $\begin{array}{l}\text { Do you know how to set the refrigerator thermostat so that } \\
\text { refrigerator temperature is within the recommended range? If yes, } \\
\text { what information is normally considered before adjusting the } \\
\text { thermostat? }\end{array}$ & $\begin{array}{l}\text { Yes; } \\
\text { No; } \\
\text { Don't know }\end{array}$ \\
\hline $\begin{array}{l}\text { To make your refrigerator colder, which way do you adjust the } \\
\text { thermostat? }\end{array}$ & $\begin{array}{l}\text { Towards the lower } \\
\text { Towards the higher number; } \\
\text { Not sure }\end{array}$ \\
\hline $\begin{array}{l}\text { Refrigerator Cleanliness How often is the inside of your } \\
\text { refrigerator cleaned? }\end{array}$ & $\begin{array}{l}\text { Once a week; Once a } \\
\text { fortnight }\end{array}$ \\
\hline
\end{tabular}




\begin{tabular}{|c|c|}
\hline & $\begin{array}{l}\text { Every month; Every } 36 \\
\text { months } \\
\text { Only if there is a spill; Other } \\
\text { (please specify) }\end{array}$ \\
\hline $\begin{array}{l}\text { Placement of foods in refrigerator: Raw meat ; Raw poultry; } \\
\text { Milk; Cooked meats e.g. Ham; Fruit and vegetables; Yogurt; Fruit } \\
\text { juice; Ready to eat salads e.g. Coleslaw; Mayonnaise }\end{array}$ & $\begin{array}{l}\text { Top; Middle; Bottom shelf ; } \\
\text { Salad boxes; Top of } \\
\text { refrigerator door; Middle } \\
\text { door; bottom of refrigerator } \\
\text { door }\end{array}$ \\
\hline $\begin{array}{l}\text { Use by dates How often do you check the 'use by' date on a food } \\
\text { before.. Buying ; Preparing food; Freezing food; Consuming food }\end{array}$ & $\begin{array}{l}\text { Never; Rarely ; Sometimes; } \\
\text { Most of the time; Always }\end{array}$ \\
\hline $\begin{array}{l}\text { about 'use by' dates on refrigerated foods, please indicate which } \\
\text { of the following statements best describes you? }\end{array}$ & $\begin{array}{l}\text { I don't check the date on the } \\
\text { label ; I always/ often/ } \\
\text { sometimes / never eat past } \\
\text { the storage instructions on } \\
\text { label } \\
\text { I don't eat this food; No label }\end{array}$ \\
\hline $\begin{array}{l}\text { Storage instructions Thinking about 'storage instructions' on } \\
\text { refrigerated foods, please indicate which of the following } \\
\text { statements best describes you? }\end{array}$ & $\begin{array}{l}\text { I don't check the storage ; } \\
\text { label instructions I always/ } \\
\text { often/ sometimes / never eat } \\
\text { past the storage instructions } \\
\text { on label ; I don't eat this food; } \\
\text { No label }\end{array}$ \\
\hline \multicolumn{2}{|l|}{ SECTION. C: REFRIGERATOR SAFETY KNOWLEDGE } \\
\hline Question & Response options \\
\hline $\begin{array}{l}\text { To prevent food poisoning what should your refrigerators } \\
\text { operating temperature be? }\end{array}$ & $\begin{array}{l}-5^{0} \mathrm{C}-5^{0} \mathrm{C} ; 2-10^{0} \mathrm{C} \\
0-8^{0} \mathrm{C} ; 0-5^{0} \mathrm{C} ;-2-8^{0} \mathrm{C} \\
\text { Don't know }\end{array}$ \\
\hline Which part of a refrigerator is normally the coldest? & $\begin{array}{l}\text { Top; Middle Bottom shelf; } \\
\text { Don't know }\end{array}$ \\
\hline Where is the recommended place to put a thermometer? & $\begin{array}{l}\text { Top; Middle Bottom shelf; } \\
\text { Don't know }\end{array}$ \\
\hline $\begin{array}{l}\text { Which one of the following ways is safest for checking if a } \\
\text { refrigerator temperature is within the recommended? }\end{array}$ & $\begin{array}{l}\text { Checking if the food in the } \\
\text { refrigerator feels cold to } \\
\text { touch } \\
\text { Using a refrigerator } \\
\text { thermometer }\end{array}$ \\
\hline
\end{tabular}




\begin{tabular}{|c|c|}
\hline & $\begin{array}{l}\text { Checking the refrigerator } \\
\text { temperature control setting } \\
\text { (thermostat) } \\
\text { Using the refrigerator LCD } \\
\text { display reading } \\
\text { Don't know }\end{array}$ \\
\hline $\begin{array}{l}\text { Which of the following are high risk in terms of food poisoning } \\
\text { risk? }\end{array}$ & $\begin{array}{l}\text { Select all mentioned from } \\
\text { below: } \\
\text { Raw Meat/Poultry } \\
\text { Milk; Cooked meats } \\
\text { Fruit and vegetables } \\
\text { Yogurt; Fruit Juice } \\
\text { Ready to eat Salads } \\
\text { Cheese; Leftover rice } \\
\text { Ready meals;Smoked fish. } \\
\text { None above }\end{array}$ \\
\hline $\begin{array}{l}\text { When a cooked chicken that will be served cold tomorrow, which } \\
\text { one of the following should you do? }\end{array}$ & $\begin{array}{l}\text { Put it in the refrigerator while } \\
\text { still hot } \\
\text { Cover it and put it in a cool } \\
\text { place for } 1-2 \text { hours and then } \\
\text { put it in the refrigerator } \\
\text { Turn off the oven and leave } \\
\text { the chicken there for } 1-2 \\
\text { hours and then put it in the } \\
\text { refrigerator } \\
\text { Cover it, leave it to cool } \\
\text { overnight on the kitchen } \\
\text { counter and the put in the } \\
\text { refrigerator }\end{array}$ \\
\hline How often should the inside of a refrigerator be cleaned? & $\begin{array}{l}\text { Once a week } \\
\text { Once a fortnight } \\
\text { Every month } \\
\text { Every } 3 \text { months } \\
\text { Every } 6 \text { months } \\
\text { Only if there is a spill }\end{array}$ \\
\hline
\end{tabular}




\begin{tabular}{|c|c|}
\hline & Other (please specify) \\
\hline What are the safest two ways to defrost raw meat? & $\begin{array}{l}\text { In the sink covered in water; } \\
\text { On the top/ bottom shelf of } \\
\text { refrigerator } \\
\text { On the kitchen counter; In a } \\
\text { microwave oven immediately } \\
\text { before cooking; Don't know }\end{array}$ \\
\hline $\begin{array}{l}\text { How long is it safe to cook raw meat / cooked foods after it has } \\
\text { been defrosted (thawed) }\end{array}$ & $\begin{array}{l}\text { Within } 24,48,72 \text { hours; } \\
\text { Within } 96 \text { hours (four days) } \\
\text { Don't know }\end{array}$ \\
\hline Where is the safest place to store raw meat in your refrigerator? & $\begin{array}{l}\text { Top shelf } \\
\text { Middle shelves } \\
\text { Bottom shelf } \\
\text { Where there is space } \\
\text { Don't know }\end{array}$ \\
\hline $\begin{array}{l}\text { How long is it safe to eat refrigerated food that was left over from } \\
\text { cooked meal? }\end{array}$ & $\begin{array}{l}\text { Within } 24,48,72 \text { hours; } \\
\text { Within } 96 \text { hours (four days) } \\
\text { Don't know }\end{array}$ \\
\hline $\begin{array}{l}\text { I am going to read you a statement and ask you to select two } \\
\text { correct responses to complete the statement....... 'After the 'use } \\
\text { by' date a refrigerated food is......' }\end{array}$ & $\begin{array}{l}\text { Still safe to eat if it looks and } \\
\text { smells ok } \\
\text { No longer safe to ear and } \\
\text { should always be discarded } \\
\text { Safe to eat if it was frozen } \\
\text { before the 'use by' date and } \\
\text { used within } 24 \text { hours of being } \\
\text { thawed } \\
\text { Safe to eat if it was frozen } \\
\text { before the 'use by' date and } \\
\text { used within } 48 \text { hours of being } \\
\text { thawed }\end{array}$ \\
\hline $\begin{array}{l}\text { I am going to read you a statement and ask you to select one } \\
\text { correct response to complete the statement....... 'After the 'best } \\
\text { before' date a refrigerated food is......' }\end{array}$ & $\begin{array}{l}\text { Still safe to eat but it may } \\
\text { begin to lose its flavour and } \\
\text { texture } \\
\text { No longer safe to ear and } \\
\text { should always be discarded }\end{array}$ \\
\hline
\end{tabular}




\begin{tabular}{|l|l|}
\hline $\begin{array}{l}\text { A perishable refrigerated food should be always be thrown away if } \\
\text { it is left at room temperature for longer than.......... }\end{array}$ & $\begin{array}{l}30 \text { minutes } \\
1,2,3, \text { hour(s) ; } \\
\text { Don't know }\end{array}$ \\
\hline $\begin{array}{l}\text { After a food with a 'use by' date has been opened which two of } \\
\text { the following are most important in determining if the food is safe } \\
\text { to eat }\end{array}$ & 'Use by' date \\
& $\begin{array}{l}\text { Look and Smell if the food; } \\
\text { Storage instructions on the } \\
\text { label e.g. number of days to } \\
\text { be consumed once open } \\
\text { 'Display until' date }\end{array}$ \\
Don't know
\end{tabular}

\section{Section D. CONSUMER PERCEPTIONS}

\begin{tabular}{|c|c|c|}
\hline & Item & $\begin{array}{l}\text { Response } \\
\text { Options }\end{array}$ \\
\hline \multirow{5}{*}{ 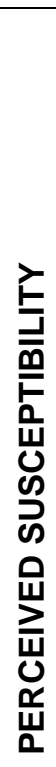 } & $\begin{array}{l}\text { If I don't know follow 'use by' instructions I will be more likely to develop } \\
\text { food poisoning } \\
\text { If I don't use leftovers within 2-3 days I will be more likely to develop food } \\
\text { poisoning }\end{array}$ & \multirow{5}{*}{$\begin{array}{l}\begin{array}{l}\text { Strongly } \\
\text { disagree }\end{array} \\
\text { Disagree } \\
\text { Neither } \\
\text { agree nor } \\
\text { disagree } \\
\text { Agree } \\
\text { Strongly } \\
\text { agree }\end{array}$} \\
\hline & $\begin{array}{l}\text { If I don't follow the current advice for defrosting food I will be more likely to } \\
\text { develop food poisoning }\end{array}$ & \\
\hline & $\begin{array}{l}\text { If I don't maintain my refrigerator temperature within } 0-5 \text { I will be more likely } \\
\text { to develop food poisoning }\end{array}$ & \\
\hline & $\begin{array}{l}\text { If I don't clean my refrigerator regularly (at least once a month) I will be } \\
\text { more likely to develop food poisoning }\end{array}$ & \\
\hline & $\begin{array}{l}\text { If I don't store raw and cooked food separately I will be more likely to } \\
\text { develop food poisoning }\end{array}$ & \\
\hline \multirow{5}{*}{ 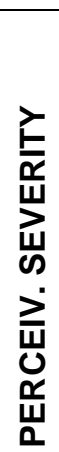 } & Food poisoning could be serious for me and my household & \multirow{5}{*}{$\begin{array}{l}\begin{array}{l}\text { Strongly } \\
\text { disagree }\end{array} \\
\text { Disagree } \\
\text { Neither } \\
\text { agree nor } \\
\text { disagree }\end{array}$} \\
\hline & $\begin{array}{l}\text { Food poisoning could affect my health/health of my household in the long- } \\
\text { term }\end{array}$ & \\
\hline & Food poisoning can result in hospitalisation & \\
\hline & Food poisoning can be fatal & \\
\hline & Developing food poisoning would NOT have a major effect on my life & \\
\hline
\end{tabular}




\begin{tabular}{|c|c|c|}
\hline & $\begin{array}{l}\text { Developing food poisoning would have serious financial consequences for } \\
\text { my household }\end{array}$ & $\begin{array}{l}\text { Agree } \\
\text { Strongly } \\
\text { agree }\end{array}$ \\
\hline \multirow{8}{*}{ 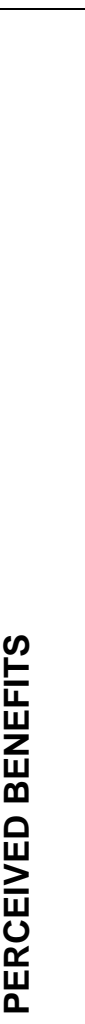 } & $\begin{array}{l}\text { Having a refrigerator thermometer would reduce our household risk of } \\
\text { developing food poisoning }\end{array}$ & \multirow{8}{*}{$\begin{array}{l}\text { Strongly } \\
\text { disagree } \\
\text { Disagree } \\
\text { Neither } \\
\text { agree nor } \\
\text { disagree } \\
\text { Agree } \\
\text { Strongly } \\
\text { agree }\end{array}$} \\
\hline & $\begin{array}{l}\text { Regularly checking and adjusting refrigerator temperature to within the } \\
\text { recommended range would reduce the risk of my household developing } \\
\text { food poisoning }\end{array}$ & \\
\hline & $\begin{array}{l}\text { Using or freezing food within the 'use by' date would reduce my household } \\
\text { risk }\end{array}$ & \\
\hline & $\begin{array}{l}\text { Following the current advice on where to place raw and cooked foods in my } \\
\text { refrigerator would reduce my household risk }\end{array}$ & \\
\hline & $\begin{array}{l}\text { Following the storage instructions on food labels e.g. Number of days to } \\
\text { consume product once open would reduce my household risk }\end{array}$ & \\
\hline & $\begin{array}{l}\text { Following the current advice for refrigerating leftovers would reduce my } \\
\text { household risk }\end{array}$ & \\
\hline & Regularly cleaning my refrigerator would reduce my household risk & \\
\hline & $\begin{array}{l}\text { Following the current advice for defrosting food would reduce my household } \\
\text { risk }\end{array}$ & \\
\hline \multirow{12}{*}{ 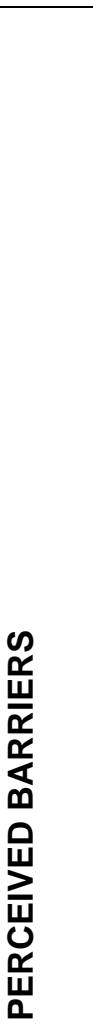 } & Accessing a refrigerator thermometer i.e. Knowing where to buy one & \multirow{12}{*}{$\begin{array}{l}\text { No problem } \\
\text { A little } \\
\text { problem } \\
\text { Somewhat of } \\
\text { a problem } \\
\text { Moderate } \\
\text { problem } \\
\text { Big Problem }\end{array}$} \\
\hline & Finding the time to check the refrigerator temperature & \\
\hline & A lack of knowledge on the correct storage of food & \\
\hline & Following the current advice for correct storage of food & \\
\hline & Following the current advice for refrigerating leftovers & \\
\hline & A lack of knowledge on the correct storage of leftovers & \\
\hline & Finding the time to clean my refrigerator regularly & \\
\hline & Following the current advice for defrosting food & \\
\hline & A lack of knowledge on the correct way to defrost foods & \\
\hline & Not understanding 'use by' dates on food labels & \\
\hline & Not understanding storage instructions on food labels & \\
\hline & $\begin{array}{l}\text { The design/layout of my refrigerator in following current advice for the } \\
\text { correct storage food }\end{array}$ & \\
\hline س م & I feel confident I know how to store refrigerated food safely & \\
\hline
\end{tabular}




\begin{tabular}{|c|c|}
\hline $\begin{array}{l}\text { I feel confident that I can maintain my refrigerator temperature within the } \\
\text { recommended range }\end{array}$ & \multirow{8}{*}{$\begin{array}{l}\begin{array}{l}\text { Strongly } \\
\text { disagree }\end{array} \\
\text { Disagree } \\
\text { Neither } \\
\text { agree nor } \\
\text { disagree } \\
\text { Agree } \\
\text { Strongly } \\
\text { agree }\end{array}$} \\
\hline $\begin{array}{l}\text { I can personally do a lot to prevent growth of bacteria in the food in my } \\
\text { refrigerator }\end{array}$ & \\
\hline I can access information on how to store refrigerated food correctly & \\
\hline $\begin{array}{l}\text { I feel confident in using 'use by' dates on food labels to check if a } \\
\text { refrigerated food is safe to eat }\end{array}$ & \\
\hline $\begin{array}{l}\text { I feel confident in using the storage instructions on food labels in order to } \\
\text { store food correctly }\end{array}$ & \\
\hline I feel confident that I know how to defrost food safely in my refrigerator & \\
\hline I feel confident I can clean my refrigerator regularly & \\
\hline I feel confident I know where to store raw meat safely within my refrigerator & \\
\hline
\end{tabular}

